\section{Weed Technology}

www.cambridge.org/wet

\section{Erratum}

Cite this article: Walsh MJ, Rayner AE, Ruttledge A, Broster JC (2021) Influence of chaff and chaff lines on weed seed survival and seedling emergence in Australian cropping systems - ERRATUM. Weed Technol. 35: 522. doi: 10.1017/wet.2021.25

First published online: 28 April 2021

\section{Keywords:}

Chaff lining; chaff tramlining; harvest weed seed control; erratum (c) The Author(s), 2021. Published by Cambridge University Press on behalf of the Weed Science Society of America.

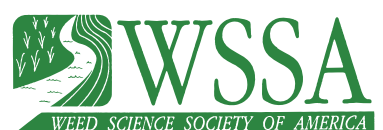

\title{
Influence of chaff and chaff lines on weed seed survival and seedling emergence in Australian cropping systems - ERRATUM
}

\section{Michael J. Walsh, Annie E. Rayner, Annie Ruttledge and John C. Broster}

https://doi.org/10.1017/wet.2020.142, published by Cambridge University Press, 26 February 2021.

In the original publication of this article (Walsh et al. 2021), the final panel of Figure 3, Figure $3 \mathrm{D}$, was mistakenly omitted. The correct version of Figure 3 appears below.

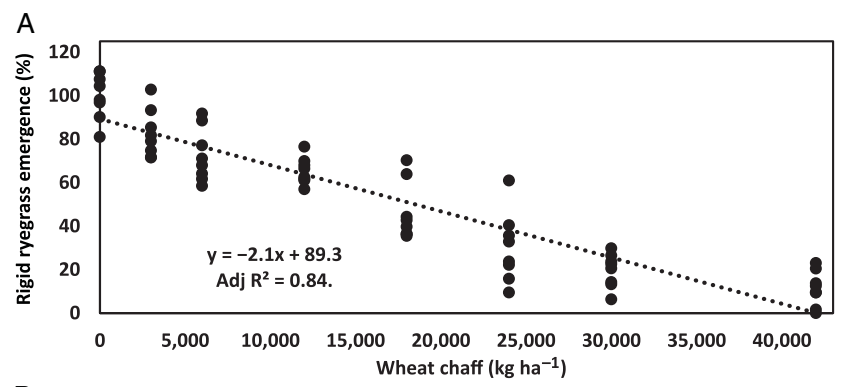

B
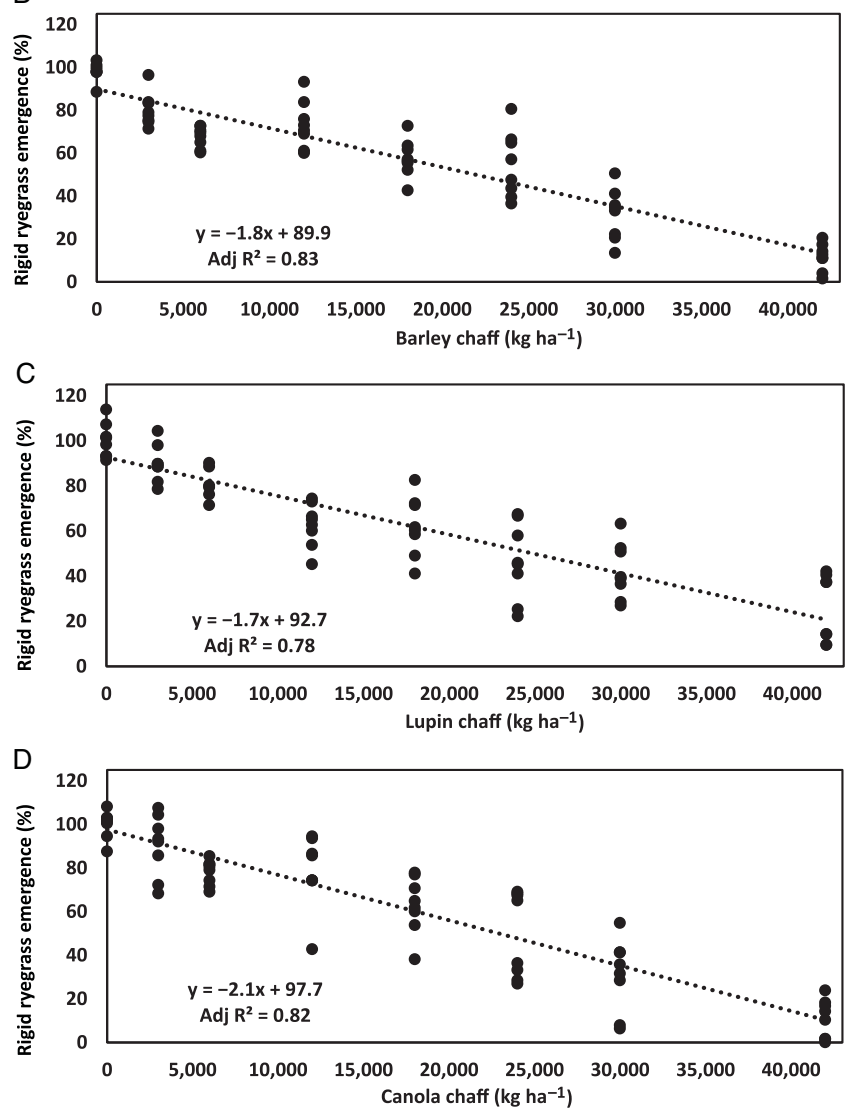

Figure 3. Rigid ryegrass seedling emergence in response to increasing amounts of (A) wheat, (B) barley, (C) lupin, and (D) canola chaff in pot trials conducted at Wagga Wagga during the 2018 and 2019 winter growing seasons. Dotted lines indicate linear relationship between chaff amount and rigid ryegrass seedling emergence.

The publisher apologizes for this error.

\section{Reference}

Walsh MH, Rayner AE, Ruttledge A, Broster JC (2021) Influence of chaff and chaff lines on weed seed survival and seedling emergence in Australian cropping systems. Weed Technol. doi: 10.1017/wet.2020.142 